\title{
Etiology of Antisperm Antibodies in the Serum of Virgins
}

\author{
Ali A. Al-Fahham \\ Basic Science Department, Faculty of Nursing, University of Kufa, Najaf, Iraq \\ Email: aliaz.mahdi@uokufa.edu.iq
}

How to cite this paper: Al-Fahham, A.A. (2018) Etiology of Antisperm Antibodies in the Serum of Virgins. Open Journal of Obstetrics and Gynecology, 8, 236-245. https://doi.org/10.4236/ojog.2018.83025

Received: February 13, 2018

Accepted: March 13, 2018

Published: March 16, 2018

Copyright $\odot 2018$ by author and Scientific Research Publishing Inc. This work is licensed under the Creative Commons Attribution International License (CC BY 4.0).

http://creativecommons.org/licenses/by/4.0/

\begin{abstract}
Background: The study of ASA etiology is very important in the diagnosis and treatment of infertility. Studies of presence of antisperm antibodies in the bodies of unmarried women are very rare, so that this article aims at studying the possible causes and interpretations behind the development of antisperm antibodies in virgins. Methodology: The study included 5 single women with positive ASA. Description and clinical history of the patients was assessed by special questionnaire provided for this purpose. All laboratory investigations and diagnostic procedures were done in the hospital from 1st August to 15th December 2017. Results: The mean serum antisperm antibody concentrations $(64.3 \mathrm{IU} / \mathrm{ml})$ which is considered positive titer. The incidence of ASA among virgins is $2.22 \%$. Complete blood count is normal except for slight increase in WBC count and percentage of basophils, monocytes and lymphocytes. This study recorded high concentrations of serum total IgG and IgM levels (1875 $\mathrm{IU} / \mathrm{ml}$ and $295 \mathrm{IU} / \mathrm{ml}$ respectively). The UTI was confirmed by counting total bacterial concentration $(178,250 \mathrm{CFU} / \mathrm{ml})$ in the urine, and diagnosis of suspected causes showed the following species: Escherichia coli, Klebsiella pneumonia, Staphylococcus aureus, and Proteus mirabilis. Conclusions: There are two suggested mechanisms to explain ASA in virgins: 1) antigen cross-reactivity between sperm and bacterial antigens to which antibodies can react; 2 ) induction of the immune system by antigens of sperm ingested into the gastrointestinal tract with contaminated food and drink. Recommendations: it is recommended to conduct a research study that include a large number of virgins for investigating ASA to confirm our results and build a scientific generalizations, in addition to animal studies for testing the role of sperm ingestion in the induction of immune system.
\end{abstract}

\section{Keywords}

Antisperm, Antibodies, Virgins, Infertility, Case-Study 


\section{Introduction}

A number of hypotheses have been suggested to explain the etiology of antisperm antibodies in both genders. In particular, several controversial studies had been conducted to investigate the occurrence and types of antisperm antibodies in women [1]. Sperm is considered as a highly diverse antigenic cell, it contains antigens that can be modified during processes of maturation and ejaculation, e.g. the binding of soluble fibronectin to the tail of sperm [2]. During the early years of the 20th century, researchers had shown that spermatozoal and seminal plasma antigenic components can stimulate both specific autoimmunity and isoimmunity. For women exposed to sexual activity, antisperm antibodies may be developed in their body after spermatozoal discharge into the reproductive tract with an immunologically settled epithelial tissue, the peritoneal cavity, or the digestive tract [3]. Exposure to sperm after oral or anal intercourse has been associated with the formation of antisperm antibodies in both women and homosexual men [4]; Wolff and Schill (1985) investigated ASA in men involved with forbidden homosexual intercourse, they recorded a high incidence of antisperm antibodies in the sera of homosexual men, they explained that high incidence by inducing immune system with antigens from spermatozoal cells through passive anal intercourse [5]. Several sperm-specific antigens have been defined using bioeffective monoclonal antibodies mAbs; These mAbs have been raised against sperm cells of various mammalian species, including mouse, rabbit, guinea pig, and human. Some of mAbs have been investigated for cross-reaction with the human sperm cell, and it is envisaged that some of the reactive cognate antigens will be conserved evolutionarily among sperm of various mammalian species and others may be highly species specificity [6].

It was found that cervical epithelial mucus is an essential element of immune system with high capacity in responding to microbial infectious agents, foreign antigens and, occasionally spermatozoal antigens. Plasma cells of the sub-epithelial layer of ovarian tubes, uterus and vagina, have the ability to produce immunoglobulin class A [7]. Like other mucosal surfaces, the secretions and tissues of the female genital tract contain antibodies, antibody-producing cells (plasma cells) in addition to other lymphatic cells, macrophages, and helper T lymphocytes [8]. Secretory IgA is the most abundant immunoglobulin in the genital tract secretions, especially in cervix, uterus and uterine tubes. Other types of immunoglobulins like IgG and may be IgM are also present. The ratio of IgA: IgG in cervical is much higher in mucus than that in serum [6]. The identification of Ig subclasses of cervical mucus antibodies showed that about $70 \%$ of the IgA was IgAl, whereas IgG4 and IgG3 were the major IgG subclasses present [7] [9]. It has been suggested that antisperm antibodies may form in women because of a decrease of one or more immunosuppressive factors in her husband's seminal fluid as sperm cells may possess protective mechanisms that inhibit immune reactions, but there is no convincing evidence to aid this hypothesis [10] [11].

Many authors mentioned that the female have the ability to potentially form 
anti-idiotype antibodies that are directed against the male husband's antibodies specific for internal sperm structures, as well as to antibodies specific for antigenic structures of sperm cells [12]. The hypothesis of idiotype antibodies is widely supported by the studies of several researchers [13].

Although antisperm antibodies in married women and adult males are well studied, no adequate studies were conducted to investigate the possible presence of antisperm antibodies in the bodies of unmarried women that have not exposed sexual activity (virgins). Many authors did not found any levels of ASA in the serum of virgin women [7]. Many others have recorded detectable concentrations of ASA in the serum of unmarried women that did not have any sexual activity [14].

This article is a descriptive study about the occurrence of antisperm antibodies in the serum of a virgin woman. As the studies of the ASA in the virgins are very rare, perhaps due to social determinants which assume that sperm do not contact with virgin body, so it aims at studying, in more details, the possible causes and interpretations behind the development of antisperm antibodies in virgins.

\section{Methodology}

\subsection{Patients Description}

A suitable questionnaire was designed to assess the socio-demographic characteristics of the virgin women that exhibit positive ASA test (Table 1).

\subsection{Clinical History}

Clinical assessment for the medical history for the virgin women was conducted through direct interview, ultrasound diagnosis, and medical laboratory analyses. Out of 255 single women investigated, only 5 had positive serum ASA. The main infectious disease was urinary tract infections, one woman suffered from colitis (Table 2). Assessment and all laboratory investigations were achieved from 1 st to 15 th December 2017.

Table 1. Socio-demographic characteristics of the ASA positive virgins.

\begin{tabular}{|c|c|c|c|}
\hline Property & & Frequency & Percentage \\
\hline \multirow{2}{*}{ Age } & $20-22$ & 2 & 40 \\
\hline & $23-25$ & 3 & 60 \\
\hline \multirow{2}{*}{ Residence } & urban & 4 & 80 \\
\hline & rural & 1 & 20 \\
\hline \multirow{2}{*}{ Monthly income } & Sufficient & 4 & 80 \\
\hline & Insufficient & 1 & 20 \\
\hline \multirow{2}{*}{ BMI } & $18.5-24.9$ & 2 & 40 \\
\hline & $25-29.9$ & 3 & 60 \\
\hline \multirow{2}{*}{ Occupation } & Laboratory technician & 1 & 20 \\
\hline & Housewife & 4 & 80 \\
\hline
\end{tabular}


Table 2. Clinical characteristics of the ASA positive virgins.

\begin{tabular}{|c|c|c|c|}
\hline Property & & Frequency & Percentage \\
\hline \multirow{2}{*}{ Ovarian or uterine tumor } & Yes & 0 & 0 \\
\hline & No & 5 & 100 \\
\hline \multirow{2}{*}{ Polycystic texture } & Yes & 0 & 0 \\
\hline & No & 5 & 100 \\
\hline \multirow{2}{*}{ Diabetes mellitus } & Yes & 0 & 0 \\
\hline & No & 5 & 100 \\
\hline \multirow{2}{*}{ Hypertension } & Yes & 0 & 0 \\
\hline & No & 5 & 100 \\
\hline \multirow[b]{2}{*}{ UTI } & Yes & 4 & 80 \\
\hline & No & 1 & 20 \\
\hline \multirow[t]{2}{*}{ Colitis } & Yes & 3 & 60 \\
\hline & No & 2 & 40 \\
\hline \multirow[t]{2}{*}{ Skin allergy } & Yes & 2 & 40 \\
\hline & No & 3 & 60 \\
\hline \multirow[t]{2}{*}{ Respiratory allergy } & Yes & 2 & 40 \\
\hline & No & 3 & 60 \\
\hline \multirow[t]{2}{*}{ Menstrual disturbances } & Yes & 1 & 20 \\
\hline & No & 4 & 80 \\
\hline \multirow[t]{4}{*}{ Drugs } & Esomeprazole & 1 & 20 \\
\hline & Salbutamol & 1 & 20 \\
\hline & Hydrocortisone & 1 & 20 \\
\hline & No drug & 2 & 40 \\
\hline
\end{tabular}

\subsection{Laboratory Tests}

\subsubsection{Investigations of Serum ASA}

The concentration of serum ASA was estimated by using Enzyme-Linked Immunosorbent Assay (ELISA) kits equipped by DRG International, Inc., USA. The cutoff point for serum ASA concentration was $60 \mathrm{IU} / \mathrm{ml}$ (above which the sample was considered positive as fixed on the kit instruction). To avoid unintended technical error, the test was repeated three times on different periods, the mean value was calculated [15].

\subsubsection{Complete Blood Count}

For counting complete blood picture, $3 \mathrm{ml}$ of blood was taken by using sterile syringe and put in heparinized tube, the test was done by using HumaCount System (Germany).

\subsubsection{Total Serum IgG and IgM}

Radial immunodiffusion is a simple technique that is routinely used for measur- 
ing the concentrations of various soluble immunoglobulines (usually proteins) in biological fluids. It is principally derived from the work of Mancini [16].

\subsubsection{Urine Culture}

All urine samples were cultured on Blood and MacConkey agar. Finding of 100,000 colony-forming units per milliliter (CFU/mL) or more was a "positive" test result symbolizing infection. The isolated bacteria were identified according to microscopic, biochemical tests and VITEK ${ }^{\circledast} 2$ system (bioMérieux) [17].

\section{Results}

Table 1 shows the socio-demographic characteristics of the ASA positive virgins, it reveals that most of them (60\%) are between 23 - 25 years old, about (80\%) of them live in urban residence, with sufficient monthly income (80\%), and a moderate BMI ranging (18.5 - 24.9) and (25 - 29.9) indicating $40 \%$ and $60 \%$ respectively. Table 2 demonstrate the clinical characteristics of the ASA positive virgins, it shows that there is no many health problems except for: urinary tract infection $(80 \%)$, skin allergy (40\%), respiratory allergic problem $(40 \%)$, and colitis $(60 \%)$. Table 3 shows that the percentage of positive serum ASA among virgins is $(2.22 \%)$, as only 5 cases indicated positive tests out of (225) volunteers participated in the research.

Table 4 shows the mean $(64.3 \mathrm{IU} / \mathrm{ml})$ and standard deviation $(1.6 \mathrm{IU} / \mathrm{ml})$ serum antisperm antibody concentrations, it is considered positive depending on the kit instruction. This result was obtained after testing 56 negative subjects. According to Table 5, measures of the complete blood count are normal except for WBC count and percentage of basophils, monocytes and lymphocytes, which were slightly shifted toward the high levels. Table 6 shows a high concentration of serum total IgG and IgM levels (1875 IU/ml and $295 \mathrm{IU} / \mathrm{ml} \mathrm{re}$ spectively).

As shown in Table 7 and Table 8, the UTI was confirmed by counting total bacterial concentration $(178,250 \mathrm{CFU} / \mathrm{ml})$, and diagnosis of bacterial species that involve in the infection, they include: Escherichia coli, Klebsiella pneumonia, Staphylococcus aureus, and Proteus mirabilis.

Table 3. Incidence of ASA among virgins.

\begin{tabular}{ccc}
\hline Property & Frequency & Percentage \\
\hline Positive serum ASA & 5 & 2.22 \\
Negative serum ASA & 220 & 97.78 \\
\hline
\end{tabular}

Table 4. Mean and standard deviation of serum antisperm antibodies.

\begin{tabular}{ccc}
\hline Measure & Mean \pm SD & Assessment \\
\hline Serum ASA $(\mathrm{IU} / \mathrm{ml})$ & $64.3 \pm 1.6$ & Positive \\
\hline
\end{tabular}


Table 5. Incidence of ASA among virgins.

\begin{tabular}{ccc}
\hline Measure & Mean \pm SD & Assessment \\
\hline RBC count $\left(\right.$ cell $\left.\backslash \mathrm{mm}^{3}\right)$ & $4.6^{\star} 10^{6} \pm 0.4^{\star} 10^{6}$ & Normal \\
WBC count (cell $\left.\backslash \mathrm{mm}^{3}\right)$ & $9850 \pm 945$ & Borderline (High) \\
Hb (g/dl) & $13.8 \pm 2.1$ & Normal \\
PCV (\%) & $38.4 \pm 5.4$ & Normal \\
Platelets count (cell $\left.\backslash \mathrm{mm}^{3}\right)$ & $227500 \pm 23454$ & Normal \\
Neutrophils (\%) & $54.2 \pm 6.3$ & Normal \\
Basophils (\%) & $0.9 \pm 0.1$ & Borderline (High) \\
Eosinophils (\%) & $3.5 \pm 0.98$ & Bormal \\
Monocytes (\%) & $6.4 \pm 1.6$ & Borderline (High) \\
\hline Lymphocytes (\%) & $34.2 \pm 10.6$ &
\end{tabular}

Table 6. Values of total serum IgG and IgM.

\begin{tabular}{ccc}
\hline Measure & Mean \pm SD & Assessment \\
\hline Total Serum IgG $(\mathrm{IU} / \mathrm{ml})$ & $1875 \pm 72.4$ & High \\
Total Serum IgM $(\mathrm{IU} / \mathrm{ml})$ & $295 \pm 12.6$ & Borderline (High) \\
\hline
\end{tabular}

Table 7. Values of Total urine bacterial count.

\begin{tabular}{ccc} 
Measure & Mean \pm SD & Assessment \\
\hline Total bacterial count $(\mathrm{CFU} / \mathrm{mL})$ & $178,250 \pm 15,520$ & Positive UTI \\
\hline
\end{tabular}

Table 8. Common bacterial isolates from the patients' urine.

\begin{tabular}{ccc}
\hline Isolates & No. of isolates & Percentage \\
\hline Escherichia coli & 2 & 40 \\
Klebsiella pneumonia & 1 & 20 \\
Staphylococcus aureus & 1 & 20 \\
Proteus mirabilis & 1 & 20 \\
\hline
\end{tabular}

\section{Discussion}

It is understandable to find very few data about the occurrence of ASA in virgins, one reason may return to the misconception that ASA can $t$ be detected in virgins, the other reasons is perhaps due to social determinants which assumes that sperm never contact with virgin body except through sexual intercourse. Out of 225 single women investigated in this study, only 5 subjects were positive for ASA by using ELISA method. Some researchers had got results similar to the present study; perhaps the first positive in the last century case was detected by the work of Harrison (1976), he used immunofluorescent assay to investigate for ASA in 66 virgin women and found that approximately $33 \%$ of them are positive for ASA [18], Saji et al. (1988) studied the presence of ASA in the sera of 3 virgin 
women, they found that one of them (33.33\%) had a positive ASA test [19].

According to the assessment performed in this study and the information provided by previous literature, two hypotheses can be suggested to interpret the occurrence of ASA in the serum the unmarried women (virgins); the first hypothesis is built on observations that human sperm cell have antigens that show immunological cross-reactivity with certain microbial antigens and autoantigens. Common cross-antigenicity has been observed between human and mouse spermatozoa and bacteria, parasites, viruses, fungi, and allergens [20] [21]; Shi et al. (2007) recorded that common cross-reactive antigens for immunocontraceptives can be detected between microorganisms and sperm which may induce subfertility [22]. Kennedy et al. (1988) concluded that cross-reactivity between sperm antibodies and autoantibodies, usually arises in autoimmune disease, suggests that of activation of polyclonal B cell, like that seen in autoimmune diseases, may occur in patients with sperm antibodies [13].

In the present study, the clinical history and bacterial count revealed recurrent UTI (Table 7), the laboratory investigations showed that the main bacterial causes of which are: Escherichia coli, Klebsiella pneumonia, Staphylococcus haemolyticus, and Proteus mirabilis (Table 8). Antigens from these bacteria may have common cross-reactivity with sperm antigens, this hypothesis can be supported by the researched conducted by a number of investigators, they demonstrated the presence of cross-reactivity between the antigens of spermatozoa and some microorganisms by the means of different ASA detection techniques. Common antigenicity has been detected between spermatozoa and each of: Escherichia coli, streptococcal antigens, Klebsiella pneumonia, Trichomonasvaginalis, Candida albicans, Staphylococcus aureus, Mycoplasma hominis, and Ureaplasma urealyticum [22] [23] [24] [25].

The clinical history in the current study also revealed that patients suffered from the colitis and accompanying digestive cramps (Table 2), Inflammatory bowel diseases (IBD) can be defined as chronic inflammatory disorder and relapsing illness of the gastrointestinal tract that lead to alteration in gastrointestinal histological structure and function [22] [23]. This inflammatory process leads to increased intestinal permeability and congestion in IBD patients, and subsequent immunization against pathogenic or intestinal flora antigens, which seem to have common antigen epitopes with cells of spermatozoa [26]. Rossato and Foresta (2004) reported that sperm may share some antigenic structures similar to structures against which the immune system is directed in patients with IBD [27], while Dimitrova et al. (2005) found that there is a statistically significant increase in antisperm antibody (ASA) incidence in patients with ulcerative colitis comparing to the control healthy fertile donors without any clinical symptoms of IBD at the same age [28]. In same directions, Kalaydjiev et al. (2007) showed increased levels of serum sperm antibody titer in patients with salmonellosis and shigellosis [29]; Dimitrova-Dikanarova et al. (2017) showed a linear correlation between anti- $H$. pylori antibodies and ASA, suggesting a role of $H$. pylori infection in the induction of ASA [30]. In spite of these findings, 
some researchers did not confirm such cross-reaction association [31].

The results of the current study also reveals that the immune systems of the all the virgins under study are intensely activated, this can be evidenced by the elevated levels of total serum IgG and IgM (Table 6), and the high percentages of monocytes and lymphocytes (Table 5). These findings come in agreement with the work of El-Roeiy et al. (1988) who observed that serum levels ASA in women are correlated with IgM and IgA [13].

The second hypothesis is that we present a new suggestion about the mechanism by which ASA are produced; according to the Table 1, one virgin women has worked in the hospital laboratory for many years, she handles semen samples every day, hence it is probable that sperm are ingested into the gastrointestinal tract through different ways, such as by contaminated hands, or contaminated food and drinks. This probability can be strengthened by the fact of poor hygiene is found in all health institutions in Iraq. This suggestion may supported by the work of many investigators who observed incidence of ASA in the serum of women with oral sexual practice [4], although those researchers did not find statistically significant difference in the incidence of ASA in those women, they found a slight increase in the incidence of serum ASA; Chaco et al. (1991) found that approximately $56.6 \%$ of women with oral intercourse have developed serum ASA [4], Yazdi et al. (2009) found positive ASA cases in about $20 \%$ of women exposed oral sexual activity [32].

\section{Conclusion}

The development of ASA in the patients included in this case-control study article can be understood by two suggested mechanisms: 1) antigen cross-reactivity between sperm and bacterial antigens to which antibodies can react; 2) induction of the immune system by antigens of sperm ingested into the gastrointestinal tract with contaminated food and drink.

\section{Recommendations}

As the studies of the ASA in the virgins are very rare, it is recommended to achieve a research study that include a large number of virgins for investigating ASA to confirm our results and build a scientific generalizations. We also recommend to conduct animal studies to test the role of GIT-deposited sperm in the induction of immune system.

\section{References}

[1] Isojima, S. (1989) Human Sperm Antigens Corresponding to Sperm-Immobilizing Antibodies in the Sera of Women with Infertility of Unknown Cause: Personal Review of Our Recent Studies. Human Reproduction, 4, 605-612. https://doi.org/10.1093/oxfordjournals.humrep.a136951

[2] Kosanovic, M. and Jankovic, M. (2012) Molecular Heterogeneity of Gelatin-Binding Proteins from Human Seminal Plasma. Asian Journal of Andrology, 12, 363-375.

[3] Marshburn, B. and Kutteh, W.H. (1994) The Role of Antisperm Antibodies in In- 
fertility. Fertility and Sterility, 61, 799-811.

[4] Chacho, K.J., Hage, C.W. and Shulman, S. (1991) The Relationship between Female Sexual Practices and the Development of Antisperm Antibodies. Fertility and Sterility, 56, 461-464. https://doi.org/10.1016/S0015-0282(16)54540-3

[5] Wolff, H. and Schill, W.B. (1985) Antisperm Antibodies in Infertile and Homosexual Men: Relationship to Serologic and Clinical Findings. Fertility and Sterility, 44, 673-677. https://doi.org/10.1016/S0015-0282(16)48986-7

[6] Chamley, L.W. and Clarke, G.N. (2007) Antisperm Antibodies and Conception. Seminars in Immunopathology, 29, 169-184.

[7] Naz, R.K. and Menge, A.C. (1994) Antisperm Antibodies: Origin, Regulation, and Sperm Reactivity in Human Infertility. Fertility and Sterility, 61, 1001-1013. https://doi.org/10.1016/S0015-0282(16)56747-8

[8] Beer, A. and Neaves, W. (1978) Antigenic Status of Semen from the Viewpoints of the Female and Male. Fertility and Sterility, 29, 3-22.

[9] Brazdova, A., Vermachova, M., Zidkova, J., Ulcova-Gallova, Z. and Peltre, G. (2013) Immunodominant Semen Proteins I: New Patterns of Sperm Proteins Related to Female Immune Infertility. Central European Journal of Biology, 8, 813-818. https://doi.org/10.2478/s11535-013-0214-9

[10] Olivares, S., Villanueva-Diaz, C., Hernandez, C., Arredondo, J. and Vadillo-Ortega, F. (1993) Identification and Partial Characterization of an Immunoglobulin A Protease Associated with Human Sperm. Biology of Reproduction, 49, 162-165. https://doi.org/10.1095/biolreprod49.1.162

[11] Witkin, S. (1989) Failure of Sperm-Induced Immunosuppression: Association with Antisperm Antibodies in Women. American Journal of Obstetrics and Gynecology, 160, 1166-1188. https://doi.org/10.1016/0002-9378(89)90181-6

[12] Clarke, G.N. (2009) Etiology of Sperm Immunity in Women. Fertility and Sterility, 91, 639-643. https://doi.org/10.1016/j.fertnstert.2007.11.045

[13] El-Roeiy, A.,Valesini, G., Friberg, J., Shoenfeld, Y., Kennedy, R.C., Tincani, A., Balestrieri, G. and Gleicher, N. (1988) Autoantibodies and Common Idiotypes in Men and Women with Sperm Antibodies. American Journal of Obstetrics and Gynecology, 158, 596-603. https://doi.org/10.1016/0002-9378(88)90037-3

[14] Dodsworth, N.J., Knight, V. and Rohrsheim, R. (1993) Why Virgins Attend Sexually Transmitted Disease Clinics. International Journal of STD \& AIDS, 4, 232-233. https://doi.org/10.1177/095646249300400411

[15] Diagnosis-Related Group (2012) Sperm Antibody ELISA. DRG ${ }^{\circledast}$ International Inc., USA.

[16] Mancini, G., Carbonara, A. and Heremans, J.F. (1965) Immunochemical Quantitation of Antigens by Single Radial Immunodiffusion. Immunochemistry, 2, 235-254. https://doi.org/10.1016/0019-2791(65)90004-2

[17] Wilson, M.L. and Gaido, L. (2004) Laboratory Diagnosis of Urinary Tract Infections in Adult Patients. Clinical Infectious Diseases, 38, 1150-1158.

[18] Harrison, R.F. (1976) Immunofluorescent Sperm Antibodies in Virgins (Letter). BMJ, 2, 1258. https://doi.org/10.1136/bmj.2.6046.1258-a

[19] Saji, F., Ohashi, K., Kato, M., Negoro, T. and Tanizawa, O. (1988) Clinical Evaluation of the Enzyme-Linked Immunosorbent Assay (ELISA) Kit for Antisperm Antibodies. Fertility and Sterility, 50, 644-647.

https://doi.org/10.1016/S0015-0282(16)60199-1 
[20] Nakamura, S., Tsuji, Y., Nakata, Y., Komori, S. and Koyama, K. (1994) Identification and Characterization of a Sperm Peptide Antigen Recognized by a Monoclonal Antisperm Autoantibody Derived from Vasectomized Mouse. Biochemical and Biophysical Research Communications, 205, 1503-1509. https://doi.org/10.1006/bbrc.1994.2837

[21] Kurpisz, M. and Alexander, N.J. (1995) Carbohydrate Moieties on Sperm Surface: Physiological Relevance. Fertility and Sterility, 63, 158-165. https://doi.org/10.1016/S0015-0282(16)57312-9

[22] Shi, J., Yang, Z., Wang, M., Cheng, G., Li, D., Wang, Y., Zhou, Y., Liu, X. and Xu, C. (2007) Screening of an Antigen Target for Immunocontraceptives from Cross-Reactive Antigens between Human Sperm and Ureaplasma Urealyticum. Infection and Immunity, 75, 2004-2011. https://doi.org/10.1128/IAI.01171-06

[23] Popivanov, R.P., Zhukov-Verezhnikov, N.N. and Boulanov, I.D. (1981) Heterogeneous Antigens of E. coli Similar to Antigens of Human Spermatozoa. Bulletin of Experimental Biology and Medicine, 9, 316-317.

[24] Tinneberg, H.R., Boettcher, B.A. and Cheng, C.Y. (1981) Possible Cross Reactivity of Group A Streptococcal Antigens and Antigens Related to Sperm Agglutination. Biol Immunol Reprod., 5, 49-53.

[25] Kalaydjiev, S.K., Dimitrova, D.K., Trifonova, N.L., Fichorova, R.N., Masharova, N.G., Raicheva, Y.N., Simeonova, M.N., Todorova, E.I., Todorov, V.I. and Nakov, L.S. (2002) The Age Related Changes in the Incidence of "Natural" Anti-Sperm Antibodies Suggest They Are Not Auto-/Isoantibodies. American Journal of Reproductive Immunology, 47, 65-71. https://doi.org/10.1034/j.1600-0897.2002.10054.x

[26] Sartor, R.B. (1995) Current Concepts of the Etiology and Pathogenesis of Ulcerative Colitis and Crohn's Disease. Gastroenterology Clinics of North America, 24, 475-507.

[27] Rossato, M. and Foresta, C. (2004) Antisperm Antibodies in Inflammatory Bowel Disease. Archives of Internal Medicine, 164, 2281-2283. https://doi.org/10.1001/archinte.164.20.2283

[28] Dimitrova, D., Kalaydjiev, S., Mendizova, A., Piryova, E. and Nakov, L. (2005) Circulating Antibodies to Human Spermatozoa in Patients with Ulcerative Colitis. Fertility and Sterility, 84, 1533-1535. https://doi.org/10.1016/j.fertnstert.2005.05.041

[29] Kalaydjiev, S., Dimitrova, D., Mitov, I., Dikov, I. and Nakov, L. (2007) Serum Sperm Antibodies after Diarrhoeal Diseases. Andrologia, 39, 101-108. https://doi.org/10.1111/j.1439-0272.2007.00772.x

[30] Dimitrova-Dikanarova, D.K., Lazarov, V.V., Tafradjiiska-Hadjiolova, R., Dimova, I.I., Petkova, N.U. and Krastev, Z.A. (2017) Association between Helicobacter Pylori Infection and the Presence of Anti-Sperm Antibodies. Biotechnology \& Biotechnological Equipment, 31, 1-8. https://doi.org/10.1080/13102818.2016.1258330

[31] Eggert-Kruse, W., Rohr, G., Probst, S., Rusu R., Hund, M., Demirakca, T., Aufenanger, J., Runnebaum, B. and Petzoldt, D. (1998) Antisperm Antibodies and Microorganisms in Genital Secretions-A Clinically Significant Relationship? Andrologia, 30, 61-71. https://doi.org/10.1111/j.1439-0272.1998.tb02828.x

[32] Yazdi, R.Z., Sene, A.A., Kohpaee, Z., Zadehmodaress, S., Hosseini, S. and Fallahian, M. (2009) The Correlation between Sexual Practices and the Development of Antisperm Antibodies. International Journal of Fertility and Sterility, 2, 189-192. 